\title{
PERSEPSI MAHASISWA TERHADAP PELAKSANAAN MINI CLINICAL EXAMINATION EXERCISE (MINI-CEX) PADA PROGRAM PENDIDIKAN KEPANITERAAN KLINIK
}

\author{
Gusti Raditya K, Yoyo Suhoyo, Tridjoko Hadianto \\ Fakultas Kedokteran Universitas Gadjah Mada Yogyakarta
}

\begin{abstract}
Background: Mini-CEX was developed to assess the clinical skills of students through direct observation and constructive feedback on student achievement. To test Mini-CEX well as assessment methods, it is necessary to evaluate the implementation of Mini-CEX as Mini-CEX assessment methods and benefits of the learning process, as well as the professional development of students as future doctors, in the form of assessment of students' perceptions of the MiniCEX implementation. The objective of this study are to validate an instrumen for measuring the level of student perceptions in the implementation of Mini-CEX in Faculty of Medicine, Universitas Gadjah Mada's clerkship program, to know the student's opinions about the implementation of Mini-CEX as a method of assessment in clerkship program and benefits to student learning and professional development, to know the relationship students' Mini-CEX point to student's perception in the implementation of Mini-CEX in clerkship program medical faculty of GMU, and to compare the perceptions of students in Mini-CEX implementation in clerkship program Medical Faculty of GMU based on the characteristics of the department.

Method: Research was conducted with a cross sectional study design. The research utilized closed questionnaires, each contained 5 likert scales. The questionnaires were given to the students who conducted clerkship in Faculty of Medicine, Universitas Gadjah Mada during the period of September 2010-March 2011. A total number of 103 students who become subjects in this study, which are consisted of 72 students in Internal Medicine Department and 32 students in Neurology Department. The correlation between student perception and Mini-CEX score was analyzed by using spearman correlation test. Mann-Whitney test was used to analyze the differences student perception between both Departments. Results: Students who are conducting clerkship program in Internal Medicine Department and Neurology Department Faculty of Medicine Universitas Gadjah Mada agree that Mini-CEX can be as assessment and learning tools, and promote the development of student professionalism. Perceptions of students towards the implementation of Mini-CEX in clerkship are not associated with Mini-CEX score. There was no significant difference in students' perceptions towards the implementation of Mini-CEX between Internal Medicine Department students and Neurology Department students. Conclusion: Students perceived the Mini-CEX to be a practical assessment tool with a positive impact on their learning and professionalism development during clerkship.
\end{abstract}

Keywords: Mini-CEX, perception, assessment method, learning media, development of professionalism, internal medicine department, neurology department.

\begin{abstract}
ABSTRAK
Latar Belakang: Mini-CEX dikembangkan untuk menilai keterampilan klinis mahasiswa melalui observasi langsung dan feedback konstruktif terhadap pencapaiannya. Untuk menguji Mini-CEX sebagai metode penilaian yang baik, maka perlu dilakukan evaluasi terhadap pelaksanaan Mini-CEX sebagai metode penilaian dan manfaat Mini-CEX terhadap proses pembelajaran serta perkembangan profesionalitas mahasiswa sebagai calon dokter dalam bentuk penilaian persepsi mahasiswa terhadap pelaksanaan Mini-CEX. Tujuan penelitian ini adalah untuk mengetahui pendapat mahasiswa tentang pelaksanaan Mini-CEX sebagai metode penilaian di program pendidikan kepaniteraan klinik dan manfaatnya terhadap pembelajaran serta perkembangan profesionalitas mahasiswa, mengetahui hubungan nilai Mini-CEX mahasiswa terhadap persepsi mahasiswa dalam pelaksanaan Mini-CEX di
\end{abstract}

Korespondensi: yoyosuhoyo@ugm.ac.id Telp: 0274-562139 
pendidikan kepaniteraan klinik FK UGM, membandingkan persepsi mahasiswa dalam pelaksanaan Mini-CEX di pendidikan kepaniteraan klinik FK UGM berdasarkan karakteristik bagian/ stase.

Metode: Penelitian menggunakan rancangan penelitian potong lintang. Penelitian menggunakan kuesioner tertutup yang berisi 5 skala likert. Kuesioner diberikan kepada seluruh mahasiswa yang sedang menjalani kepaniteraan klinik di Fakultas Kedokteran Universitas Gadjah Mada, Yogyakarta (FK UGM), dari bulan September 2010-Maret 2011. Sebanyak 103 mahasiswa menjadi subyek pada penelitian ini, yang terdiri dari 72 mahasiswa Bagian Ilmu Penyakit Dalam dan 32 mahasiswa Bagian Ilmu Penyakit Saraf. Hubungan persepsi mahasiswa terhadap nilai Mini-CEX dianalisis dengan Uji korelasi Spearman. Perbedaan penilaian persepsi terhadap pelaksanaan Mini-CEX di kedua Bagian menggunakan Uji komparatif Mann-Whitney.

Hasil: Mahasiswa yang sedang melaksanakan program pendidikan kepaniteraan klinik pada Bagian Ilmu Penyakit Dalam dan Ilmu Penyakit Saraf FK UGM setuju Mini-CEX dapat menjadi media penilaian, media pembelajaran dan meningkatkan perkembangan profesionalisme mahasiswa dalam program pendidikan kepaniteraan klinik FK UGM. Persepsi mahasiswa terhadap pelaksanaan Mini-CEX dalam pendidikan kepaniteraan klinik FK UGM tidak berhubungan dengan hasil nilai Mini-CEX mahasiswa. Tidak terdapat perbedaan yang bermakna terhadap persepsi mahasiswa terhadap pelaksanaan Mini-CEX pada program kepaniteraan klinik FK UGM antara mahasiswa Ilmu Penyakit Dalam dan mahasiswa Ilmu Penyakit Saraf.

Kesimpulan: Mahasiswa mempersepsikan Mini-CEX sebagai media penilaian yang praktis dengan dampak yang positif terhadap pembelajaran dan perkembangan profesionalisme mereka selama kepaniteraan klinik.

Kata kunci: Mini-CEX, persepsi, metode penilaian, media pembelajaran, perkembangan profesionalisme, Bagian Ilmu Penyakit Dalam, Bagian Ilmu Penyakit Saraf

\section{PENDAHULUAN}

Fakultas Kedokteran Universitas Gadjah Mada terus menerus menginovasi dan meningkatkan sistem pendidikan kepaniteraan klinik. Salah satu inovasi dan peningkatan yang dapat dilakukan adalah menambah kualitas supervisi klinis, terutama dengan observasi langsung dan feedback pada performa klinis mahasiswa. Hal ini dapat dilakukan dengan mengimplementasikan mini-CEX sebagai metode penilaian. Untuk menilai bahwa Mini-CEX merupakan metode penilaian yang baik, maka perlu dilakukan evaluasi terhadap pelaksanaan Mini-CEX sebagai metode penilaian dan manfaat Mini-CEX terhadap proses pembelajaran, termasuk perkembangan profesionalitas mahasiswa sebagai calon dokter. ${ }^{1}$ Salah satu caranya adalah penilaian persepsi mahasiswa terhadap pelaksanaan Mini-CEX.

Mini-CEX adalah suatu metode penilaian kompetensi untuk mahasiswa yang diperkenalkan oleh American Board of Internal Medicine. ${ }^{2}$ Metode ini memberikan banyak kesempatan kepada mahasiswa untuk mendapatkan berbagai macam pasien atau kasus yang diobservasi langsung oleh supervisor. Mini-CEX dilakukan dengan cara mengobservasi interaksi mahasiswa dengan pasien untuk kemudian dinilai kompetensi klinisnya dan diberikan feedback konstruktif terhadap pencapaiannya. Terdapat 7 (tujuh) kompetensi yang menjadi fokus pada penilaian Mini-CEX, yaitu anamnesis, pemeriksaan fisik, penalaran klinis (diagnosis), manajemen pasien, komunikasi dan konsultasi, profesionalisme, dan organisasi/ efisiensi. Proses penilaian difasilitasi dengan menggunakan lembar penilaian. Sebagai metode penilaian, mini-CEX dilaporkan memiliki keterlaksanaan (feasibility) yang baik, baik menurut penguji maupun peserta ujian. ${ }^{3}$

Hasil dari penilaian Mini-CEX dapat digunakan sebagai informasi dasar untuk memberikan umpan-balik yang konstruktif (constructive feedback) langsung terhadap performa mahasiswa. ${ }^{4,5,6} \mathrm{Hal}$ ini diketahui secara langsung meningkatkan pembelajaran mahasiswa. ${ }^{7,8}$ Mini-CEX meningkatkan pembelajaran mahasiswa melalui informasi tentang kemajuan atau kekurangan akan kompetensinya, arahan tentang materi yang dibutuhkan dan sumber pembelajaran yang dapat memfasilitasi pembelajaran, serta motivasi untuk mempunyai aktivitas pembelajaran yang sesuai. ${ }^{8}$ Proses yang terjadi secara terus menerus selama proses pendidikan tersebut, secara jangka panjang dapat berdampak terhadap perkembangan profesionalisme mahasiswa.

Mengingat pentingnya hal tersebut diatas, maka penelitian ini dilakukan dengan tujuan mengetahui persepsi mahasiswa tentang pelaksanaan Mini-CEX 
sebagai metode penilaian di program pendidikan kepaniteraan klinik dan manfaatnya terhadap pembelajaran serta perkembangan profesionalitas mahasiswa. Hubungan antara persepi dengan nilai Mini-CEX mahasiswa dan perbandingan persepsi berdasarkan karakteristik bagian/ stase juga diteliti.

\section{METODE}

Penelitian menggunakan rancangan penelitian potong lintang. Penelitian menggunakan kuesioner tertutup yang berisi 5 skala likert $(1$ = Sangat tidak setuju, $5=$ Sangat setuju). Terdapat 3 poin utama yang dijadikan dasar penilaian mahasiswa terhadap pelaksanaan Mini-CEX selama pendidikan kepaniteraan klinik di FK UGM, yaitu (a) Mini-CEX sebagai media penilaian sebanyak 5 pertanyaan, (b) Mini-CEX sebagai media pembelajaran sebanyak 11 pertanyaan, dan (c) Mini-CEX dalam perkembangan profesionalisme sebanyak 3 pertanyaan. Kuesioner diberikan kepada seluruh mahasiswa yang sedang menjalani kepaniteraan klinik di Bagian Ilmu Penyakit Dalam (IPD) dan Ilmu Penyakit Saraf, Fakultas Kedokteran Universitas Gadjah Mada, Yogyakarta (FK UGM), dari bulan September 2010-Maret 2011. Mahasiswa diminta mengisi lembar kuesioner penelitian secara sukarela setelah menyelesaikan kepaniteraan klinik di kedua Bagian.

Penilaian persepsi mahasiswa terhadap pelaksanaan Mini-CEX, dilakukan dengan menghitung persentase nilai jawaban kuesioner mahasiswa terhadap pelaksanaan Mini-CEX pada masing-masing bagian. Hubungan persepsi mahasiswa terhadap nilai Mini-CEX dinilai dengan cara menghitung nilai rata-rata total persepsi mahasiswa dibandingkan dengan rata-rata nilai Mini-CEX mahasiswa dengan menggunakan Uji korelasi Spearman. Sedangkan untuk mengetahui perbedaan penilaian persepsi terhadap pelaksanaan Mini-CEX di Bagian IPD dan Ilmu Penyakit Saraf, maka persepsi antara kedua bagian tersebut dibandingkan, dengan menghitung nilai rata-rata total persepsi masing-masing bagian dengan menggunakan Uji komparatif MannWhitney.

\section{HASIL DAN PEMBAHASAN}

Selama periode bulan September 2010 - Maret 2011 terdapat 74 orang mahasiswa kepaniteraan klinik Bagian IPD, dan 42 orang mahasiswa kepaniteraan klinik Bagian Ilmu Penyakit Saraf telah berpartisipasi dalam penelitian ini. Dua orang mahasiswa di Bagian IPD dieksklusi karena tidak mengisi kuesioner. Sepuluh orang mahasiswa di Bagian Ilmu Penyakit Saraf dieksklusi karena tidak mengisi kuesioner. Sehingga jumlah mahasiswa kepaniteraan klinik yang memenuhi kriteria inklusi berjumlah 72 orang dari Bagian IPD, dan 31 orang dari Bagian Ilmu Penyakit Saraf.

Uji validitas dan reabilitas dilakukan kepada seluruh responden penelitian yang berjumlah 103 mahasiswa yang sedang melakukan pendidikan kepaniteraan klinik di bagian IPD dan Ilmu Penyakit Saraf. Uji validitas instrumen ini menggunakan uji Pearson Moment Product, dengan hasil semua item memiliki korelasi yang tinggi terhadap skor totalnya. ${ }^{9,10}$ Hal ini ditunjukkan dengan seluruh item pertanyaan memiliki taraf kebermaknaan sebesar $0,01(\mathrm{p}<0.05)$.

Uji reliabilitas instrumen ini menggunakan uji Splithalf method kemudian dilanjutkan dengan pengujian dengan rumus Spearman-Brown. 9,10 Hasil korelasi antara skor item ganjil dan genap adalah 0,826. Dengan demikian, dapat dikatakan bahwa item-item di atas memiliki tingkat reliabilitas yang tinggi. 
Tabel 1. Persentase penilaian persepsi terhadap pelaksanaan Mini-CEX Bagian Ilmu Penyakit Dalam

\begin{tabular}{|c|c|c|c|c|c|c|c|}
\hline No & Item Pertanyaan & $\begin{array}{l}\text { STS } \\
(\%)\end{array}$ & $\begin{array}{l}\text { TS } \\
(\%)\end{array}$ & $\begin{array}{l}\mathrm{RR} \\
(\%)\end{array}$ & $\begin{array}{c}\mathrm{S} \\
(\%)\end{array}$ & $\begin{array}{l}\text { SS } \\
(\%)\end{array}$ & $\begin{array}{c}\text { Total } \\
(\%)\end{array}$ \\
\hline I. & Mini-CEX sebagai media penilaian & & & & & & \\
\hline 1. & Penilaian ini praktis untuk dilakukan & 0 & 1.4 & 12.5 & 73.6 & 12.5 & 100 \\
\hline 2. & $\begin{array}{l}\text { Penguji nyaman saat melakukan pengamatan } \\
\text { terhadap kemampuan saya }\end{array}$ & 0 & 1.4 & 20.8 & 69.4 & 8.3 & 100 \\
\hline 3. & $\begin{array}{l}\text { Pengamatan penting dalam penilaian keterampilan } \\
\text { klinis }\end{array}$ & 0 & 0 & 4.2 & 76.4 & 19.4 & 100 \\
\hline 4. & Lembar penilaian mudah diisi & 0 & 1.4 & 20.8 & 70.8 & 6.9 & 100 \\
\hline 5. & Kolom feedback cukup untuk diisi & 0 & 2.8 & 20.8 & 69.4 & 6.9 & 100 \\
\hline II. & Mini-CEX sebagai media pembelajaran & & & & & & \\
\hline 6. & $\begin{array}{l}\text { Membantu staf klinik untuk mengamati interaksi } \\
\text { saya dengan pasien }\end{array}$ & 0 & 1.4 & 9.7 & 77.8 & 11.1 & 100 \\
\hline 7. & $\begin{array}{l}\text { Pengamatan langsung adalah kekuatan penting } \\
\text { Mini-CEX }\end{array}$ & 0 & 0 & 2.8 & 81.9 & 15.3 & 100 \\
\hline 8. & $\begin{array}{l}\text { Memiliki dampak positif terhadap hubungan kerja } \\
\text { staf klinik dan saya }\end{array}$ & 0 & 1.4 & 15.3 & 70.8 & 12.5 & 100 \\
\hline 9. & Mempengaruhi pembelajaran saya & 0 & 1.4 & 6.9 & 73.6 & 18.1 & 100 \\
\hline 10. & $\begin{array}{l}\text { Menyiapkan saya menghadapi ujian akhir di bagian } \\
\text { ini }\end{array}$ & 0 & 0 & 12.5 & 69.4 & 18.1 & 100 \\
\hline 11. & $\begin{array}{l}\text { Feedback penguji membantu saya memperbaiki } \\
\text { kelemahan }\end{array}$ & 0 & 0 & 6.9 & 63.9 & 29.2 & 100 \\
\hline 12. & $\begin{array}{l}\text { Feedback penguji membantu dokter muda dalam } \\
\text { pelayanan terhadap pasien sehari-hari }\end{array}$ & 0 & 0 & 8.3 & 73.6 & 18.1 & 100 \\
\hline 13. & Feedback adalah kekuatan penting Mini-CEX & 0 & 0 & 4.2 & 73.6 & 22.2 & 100 \\
\hline 14. & Memiliki dampak terhadap self-directed learning saya & 0 & 0 & 15.3 & 65.3 & 19.4 & 100 \\
\hline 15 . & $\begin{array}{l}\text { Hasil Mini-CEX sebelumnya mempengaruhi saya } \\
\text { pada Mini-CEX berikutnya }\end{array}$ & 0 & 0 & 12.5 & 75.0 & 12.5 & 100 \\
\hline 16. & $\begin{array}{l}\text { Pengalaman yang diperoleh saya saat penilaian } \\
\text { Mini-CEX dapat digunakan pada kegiatan sehari- } \\
\text { hari }\end{array}$ & 0 & 1.4 & 9.7 & 79.2 & 9.7 & 100 \\
\hline III. & Mini-CEX dalam perkembangan profesionalisme & & & & & & \\
\hline 17. & $\begin{array}{l}\text { Penilaian ini mempengaruhi perkembangan sikap } \\
\text { profesional saya sebagai dokter }\end{array}$ & 0 & 0 & 11.1 & 75 & 13.9 & 100 \\
\hline 18. & $\begin{array}{l}\text { Penilaian ini mempengaruhi perspektif saya } \\
\text { mengenai pelayanan pasien }\end{array}$ & 0 & 1.4 & 8.3 & 75 & 15.3 & 100 \\
\hline 19. & $\begin{array}{l}\text { Penilaian ini mempengaruhi hubungan saya dengan } \\
\text { pasien dan keluarganya }\end{array}$ & 0 & 1.4 & 13.9 & 68.1 & 16.7 & 100 \\
\hline
\end{tabular}

Keterangan: STS = Sangat Tidak Setuju, TS = Tidak Setuju, RR = Ragu-ragu, S = Setuju, SS = Sangat Setuju 
Persentase penilaian persepsi pelaksanaan Mini-CEX pada Bagian Ilmu Penyakit Saraf dapat dilihat pada Tabel 2.

Tabel 2. Persentase penilaian persepsi terhadap pelaksanaan Mini-CEX Bagian Ilmu Penyakit Saraf

\begin{tabular}{|c|c|c|c|c|c|c|c|}
\hline No & Item Pertanyaan & $\begin{array}{l}\text { STS } \\
(\%)\end{array}$ & $\begin{array}{l}\text { TS } \\
(\%)\end{array}$ & $\begin{array}{l}\mathrm{RR} \\
(\%)\end{array}$ & $\begin{array}{l}S \\
(\%)\end{array}$ & $\begin{array}{l}\text { SS } \\
(\%)\end{array}$ & $\begin{array}{c}\text { Total } \\
(\%)\end{array}$ \\
\hline I. & Mini-CEX sebagai media penilaian & & & & & & \\
\hline 1. & Penilaian ini praktis untuk dilakukan & 0 & 16.1 & 0 & 83.9 & 0 & 100 \\
\hline 2. & $\begin{array}{l}\text { Penguji nyaman saat melakukan pengamatan } \\
\text { terhadap kemampuan saya }\end{array}$ & 3.2 & 6.5 & 19.4 & 67.7 & 3.2 & 100 \\
\hline 3. & $\begin{array}{l}\text { Pengamatan penting dalam penilaian keterampilan } \\
\text { klinis }\end{array}$ & 3.2 & 0 & 0 & 87.1 & 9.7 & 100 \\
\hline 4. & Lembar penilaian mudah diisi & 3.2 & 6.5 & 12.9 & 71 & 6.5 & 100 \\
\hline 5. & Kolom feedback cukup untuk diisi & 3.2 & 6.5 & 12.9 & 74.2 & 3.2 & 100 \\
\hline II. & Mini-CEX sebagai media pembelajaran & & & & & & \\
\hline 6. & $\begin{array}{l}\text { Membantu staf klinik untuk mengamati interaksi } \\
\text { saya dengan pasien }\end{array}$ & 6.5 & 3.2 & 0 & 67.7 & 22.6 & 100 \\
\hline 7. & $\begin{array}{l}\text { Pengamatan langsung adalah kekuatan penting } \\
\text { Mini-CEX }\end{array}$ & 3.2 & 0 & 6.5 & 58.1 & 32.3 & 100 \\
\hline 8. & $\begin{array}{l}\text { Memiliki dampak positif terhadap hubungan kerja } \\
\text { staf klinik dan saya }\end{array}$ & 3.2 & 3.2 & 16.1 & 54.8 & 22.6 & 100 \\
\hline 9. & Mempengaruhi pembelajaran saya & 3.2 & 0 & 9.7 & 61.3 & 25.8 & 100 \\
\hline 10. & $\begin{array}{l}\text { Menyiapkan saya menghadapi ujian akhir di bagian } \\
\text { ini }\end{array}$ & 3.2 & 3.2 & 6.5 & 61.3 & 25.8 & 100 \\
\hline 11. & $\begin{array}{l}\text { Feedback penguji membantu saya memperbaiki } \\
\text { kelemahan }\end{array}$ & 0 & 0 & 3.2 & 61.3 & 35.5 & 100 \\
\hline 12. & $\begin{array}{l}\text { Feedback penguji membantu dokter muda dalam } \\
\text { pelayanan terhadap pasien sehari-hari }\end{array}$ & 0 & 3.2 & 9.7 & 54.8 & 32.3 & 100 \\
\hline 13. & Feedback adalah kekuatan penting Mini-CEX & 0 & 0 & 0 & 64.5 & 35.5 & 100 \\
\hline 14. & Memiliki dampak terhadap self-directed learning saya & 0 & 0 & 3.2 & 67.8 & 29 & 100 \\
\hline 15. & $\begin{array}{l}\text { Hasil Mini-CEX sebelumnya mempengaruhi saya } \\
\text { pada Mini-CEX berikutnya }\end{array}$ & 6.5 & 9.7 & 9.7 & 45.2 & 29 & 100 \\
\hline 16. & $\begin{array}{l}\text { Pengalaman yang diperoleh saya saat penilaian } \\
\text { Mini-CEX dapat digunakan pada kegiatan sehari- } \\
\text { hari }\end{array}$ & 3.2 & 0 & 16.1 & 61.3 & 19.4 & 100 \\
\hline III. & Mini-CEX dalam perkembangan profesionalisme & & & & & & \\
\hline 17. & $\begin{array}{l}\text { Penilaian ini mempengaruhi perkembangan sikap } \\
\text { profesional saya sebagai dokter }\end{array}$ & 3.2 & 12.9 & 9.7 & 58.1 & 16.1 & 100 \\
\hline 18. & $\begin{array}{l}\text { Penilaian ini mempengaruhi perspektif saya } \\
\text { mengenai pelayanan pasien }\end{array}$ & 3.2 & 3.2 & 19.4 & 54.8 & 19.4 & 100 \\
\hline 19. & $\begin{array}{l}\text { Penilaian ini mempengaruhi hubungan saya dengan } \\
\text { pasien dan keluarganya }\end{array}$ & 3.2 & 16.1 & 6.5 & 61.3 & 12.9 & 100 \\
\hline
\end{tabular}

Keterangan: STS = Sangat Tidak Setuju, TS = Tidak Setuju, RR = Ragu-ragu, $\mathrm{S}=$ Setuju, SS = Sangat Setuju

Hasil analisis hubungan antara persepsi mahasiswa terhadap pelaksanaan Mini-CEX dengan rata-rata nilai Mini-CEX dengan menggunakan uji korelasi Spearman menunjukkan bahwa nilai kebermaknaan korelasi pada Bagian IPD adalah 0.839 ( $\mathrm{p}>0.05$ ) dan pada Bagian Ilmu Penyakit Saraf adalah 0.705 ( $\mathrm{p}>0.05)$. Hal ini menunjukkan bahwa korelasi antara persepsi mahasiswa terhadap pelaksanaan Mini-CEX dan nilai Mini-CEX Bagian IPD dan Ilmu Penyakit Saraf, keduanya tidak bermakna. Hasil penelitian juga menunjukkan bahwa terdapat perbedaan bermakna antara persepsi mahasiswa di Bagian IPD dan Bagian Ilmu Penyakit Saraf, yaitu $0.014(\mathrm{p}<0.05)$. 


\section{Mini-CEX sebagai media penilaian}

Hasil penelitian pada lima pertanyaan tentang persepsi mahasiswa terhadap Mini-CEX sebagai media penilaian di Bagian IPD menunjukan bahwa sebagian besar mahasiswa menyatakan setuju dan sangat setuju, yaitu; penilaian ini praktis untuk dilakukan (86.1\%); penguji nyaman saat melakukan pengamatan terhadap kemampuan mahasiswa (77.7\%); pengamatan penting dalam penilaian keterampilan klinis (95.8\%); lembar penilaian mudah diisi (77.7\%); dan kolom feedback cukup untuk diisi (76.3\%). Demikian juga di Bagian Ilmu Penyakit Saraf, sebagian besar mahasiswa menyatakan setuju dan sangat setuju pada kelima item tersebut yaitu; $83.9 \%, 70.9 \%, 96.8 \%, 77.5 \%$ dan $77.4 \%$. Hal ini sesuai dengan beberapa penelitian yang menunjukkan bahwa Mini-CEX memiliki keterlaksanaan yang baik., ${ }^{3,11}$ Wilkinson et $\mathrm{al}^{12}$ menyebutkan Mini-CEX dilakukan hanya sekitar 25 menit (termasuk dengan pemberian feedback), dan diantara metode penilaian yang digunakan, baik residen dan supervisor menyatakan setuju bahwa MiniCEX adalah media penilaian yang praktis untuk dilakukan dalam pengembangan kompetensi sebagai seorang dokter.

Terkait pentingnya pengamatan dalam penilaian keterampilan klinik, Hauer ${ }^{4}$ mengatakan bahwa MiniCEX digunakan untuk mengobservasi langsung mahasiswa saat melakukan keterampilan klinik, khususnya anamnesis dan pemeriksaan fisik. Selain itu, Holmboe et $\mathrm{al}^{5}$ mengatakan, pengamatan langsung (direct observation) oleh pengajar klinis adalah proses penting/ vital untuk mengevaluasi keterampilan klinik mahasiswa. Pengamatan langsung (Direct Obsevation) terhadap pelatihan kompetensi, adalah pendekatan baru dalam pengembangan pendidikan, memimpin perubahan yang berarti dalam penilaian perilaku, dan membawa kenyamanan dan kemudahan pengajar dalam mengevaluasi keterampilan klinis mahasiswanya.

Adanya kolom feedback yang cukup untuk diisi, maka akan memudahkan penguji untuk memberikan catatan terhadap kelebihan dan kekurangan yang membangun dari hasil observasi dan membuat rencana pembelajaran bagi mahasiswa. ${ }^{8}$ Dengan demikian mahasiswa dapat belajar dan dapat mengembangkan keterampilan klinis mahasiswa dari catatan yang diberikan oleh penguji.

\section{Mini-CEX sebagai media pembelajaran}

Hasil penelitian menunjukkan bahwa sebagian besar mahasiswa menyatakan setuju terhadap 11 pertanyaan terkait Mini-CEX sebagai media pembelajaran di kedua Bagian. Sebanyak 88.9\% mahasiswa di Bagian IPD dan 90.3\% mahasiswa di Bagian Ilmu Penyakit Saraf setuju dan sangat setuju Mini-CEX membantu staf klinik untuk mengamati mahasiswa dengan pasien. Hal ini sejalan dengan hasil penelitian di tingkat residen yang menunjukkan bahwa mini-CEX memiliki ketepatan yang lebih tinggi dalam penilaian kompetensi klinis mahasiswa, memberikan kesempatan penilaian pada berbagai tempat klinis dan berbagai kondisi pasien dan dilaksanakan langsung ditempat saat kontak dengan pasien. ${ }^{13}$

Pengamatan langsung sebagai kekuatan penting MiniCEX disetujui oleh sebagian besar mahasiswa baik di Bagian IPD maupun Ilmu Penyakit Saraf (97.2\% dan 90.4\%). Hal ini sejalan dengan penelitian lain yang menunjukan bahwa pengamatan langsung pada MiniCEX meningkatkan validitas dan reliabilitas penilaian mahasiswa. ${ }^{6}$ Pengamatan langsung secara terus menerusmenerus dan berkelanjutan akan menyebabkan kemampuan atau kompetensi mahasiswa dapat terukur. ${ }^{8}$

Pengamatan langsung penting untuk memberikan feedback kepada mahasiswa selama kepaniteraan klinik. ${ }^{14}$ Oleh karena itu, selain pengamatan langsung, sebagian besar mahasiswa pada Bagian IPD (95.8\%) dan seluruh mahasiswa di Ilmu Penyakit Saraf (100\%) menyatakan setuju dan sangat setuju bahwa feedback adalah kekuatan penting dalam pelaksanaan Mini-CEX. Hal ini sesuai dengan pendapat Norcini $\&$ Burch $^{8}$ yang menyatakan bahwa ketersediaan feedback adalah salah satu kekuatan utama Mini-CEX dalam memfasilitasi pembelajaran mahasiswa. Feedbak pada Mini-CEX mampu memfasilitasi proses pembelajaran karena feedback menginformasikan tentang progress (kemajuan) atau kekurangan akan kompetensinya, memberikan arahan tentang apa yang mereka butuhkan dan sumber pembelajaran yang bisa memfasilitasi pembelajaran mahasiswa dan memotivasi mereka untuk mempunyai aktivitas pembelajaran yang sesuai. ${ }^{8}$ Sehingga, pendapat bahwa penilaian mengarahkan pembelajaran mahasiswa terjadi pada penerapan Mini-CEX ini. Dengan adanya Mini-CEX, mahasiswa akan termotivasi untuk mencapai kompetensinya, memahami tujuan pembelajaran dan standar/ kriteria yang diharapkan, dan menggunakan 
feedback yang mereka terima untuk melakukan refleksi dan memperbaiki performa sehingga dapat mencapai tujuan yang telah ditetapkan. ${ }^{15} \mathrm{Hal}$ tersebut dapat terkonfirmasi pada hasil penelitian ini yang menunjukkan bahwa sebagian besar mahasiswa di Bagian IPD dan Ilmu Penyakit Saraf setuju dan sangat setuju bahwa: feedback penguji membantu mahasiswa memperbaiki kelemahan (93.1\% dan 96.8\%); memiliki dampak terhadap self-directed learning mahasiswa $(84.7 \%$ dan 96.8\%); mempengaruhi pembelajaran mahasiswa (91.7\% dan 87.1\%); menyiapkan mahasiswa menghadapi ujian akhir di bagian (87.5\% dan 87.1); dan, hasil MiniCEX sebelumnya mempengaruhi mahasiswa pada pelaksanaan Mini-CEX berikutnya (87.5\% dan $74.2 \%$ ). Hasil penelitian ini juga sejalan dengan hasil penelitian penerapan Mini-CEX di tingkat Residen yang menunjukkan bahwa Mini-CEX memberikan pengaruh yang konstruktif terhadap pembelajaran Residen. ${ }^{16}$ Sebagai dampaknya, penelitian lain menunjukkan bahwa dibandingkan dengan tahun pertama, residen mengalami peningkatan yang bermakna dalam semua aspek kompetensi yang dinilai dalam Mini-CEX. ${ }^{13}$

Selain berdampak terhadap pembelajaran mahasiswa karena memungkinkan pengajar dapat memberikan feedback yang berkualitas, Mini-CEX juga dapat membangun hubungan yang baik antara peserta didik dan pengajar, serta menjadi sarana pengawasan dan pemberian model dari pelaksanaan keterampilan klinik. Hal ini ditunjukkan dengan hasil penelitian yang menunjukkan bahwa sebagian besar mahasiswa di Bagian IPD dan Ilmu Penyakit Saraf menyatakan setuju dan sangat setuju (83.3\% dan 77.4\%) pelaksanaan MiniCEX memiliki dampak positif terhadap hubungan kerja pengajar klinik dengan mahasiswa.

Mini-CEX dilakukan empat kali di Bagian IPD dan 2 kali di Bagian Ilmu Penyakit Saraf. Menyadari dirinya akan diamati secara langsung saat berinteraksi dengan pasien untuk kemudian dinilai dan mendapatkan feedback, maka mahasiswa akan selalu belajar dan berlatih untuk menghadapi Mini-CEX selanjutnya. ${ }^{17}$ Pengalaman inilah yang dijadikan mahasiswa sebagai proses pembelajaran untuk digunakan dalam kegiatan seharihari. Hal tersebut didukung hasil penelitian yang menunjukkan bahwa sebagian besar mahasiswa di Bagian IPD dan Ilmu Penyakit Saraf setuju bahwa dalam pelaksanaan Mini-CEX, feedback penguji membantu mahasiswa dalam pelayanan terhadap pasien sehari-hari
(91,7\% dan $87,1 \%)$ dan pengalaman yang diperoleh mahasiswa saat penilaian Mini-CEX dapat digunakan pada kegiatan sehari-hari (88,9\% dan $80,7 \%)$.

\section{Mini-CEX dalam perkembangan profesionalisme}

Hasil penelitian menunjukkan bahwa sebagian besar mahasiswa di Bagian IPD dan Ilmu Penyakit Saraf menyatakan setuju dan sangat setuju terhadap ketiga pertanyaan terkait peran Mini-CEX dalam perkembangan profesionalism yaitu: penilaian dalam pelaksana-an Mini-CEX dapat mempengaruhi sikap professional mahasiswa sebagai seorang dokter (88.9\% dan $74.2 \%)$; penilaian dalam pelaksanaan Mini-CEX mempengaruhi perspektif mahasiswa terhadap pelayanan pasien $(90.3 \%$ dan 74.2\%); dan, penilaian Mini-CEX mempengaruhi hubungan mahasiswa dengan pasien dan keluarganya (84.8\% dan $74.2 \%$ ). Hasil penelitian tersebut dapat disebabkan adanya pengamatan langsung terhadap mahasiwa saat berinteraksi dengan pasien secara terus menerus sehingga pengajar mengetahui perkembangan kompetensi klinik mahasiswa yang diperlukan untuk menjadi dokter yang professional. Sikap-sikap tidak profesional yang muncul saat mahasiswa menghadapi pasien dapat diidentifikasi sejak dini. ${ }^{18}$ Hal ini dapat mencegah lahirnya dokter yang tidak profesional. Terlebih lagi, perkembangan kompetensi tersebut didokumentasikan, sehingga dapat digunakan untuk menilai profesionalitas mahasiswa secara menyeluruh. ${ }^{17,18}$ Selain itu, Mini-CEX juga memiliki predictive validity yang baik, sehingga gambaran kompetensi klinik mahasiswa di masa depan dapat tergambarkan secara dini. ${ }^{3,11}$

Mini-CEX dilaksanakan dengan melibatkan berbagai jenis kasus, sehingga mahasiswa terpapar dengan banyak pasien dan berbagai diagnosis yang terjadi dalam konteks pelayanan. ${ }^{2,8,13,19}$ Diharapkan, interaksi tersebut dapat berdampak baik terhadap cara pandang mahasiswa dalam berhubungan dan melayani pasien. Karena umumnya pasien didampingi keluarganya, hal ini juga akan berdampak terhadap hubungan mahasiswa dengan keluarga pasien.

Hal penelitian menunjukkan bahwa besar kecilnya nilai Mini-CEX mahasiswa tidak memiliki hubungan yang bermakna terhadap pelaksanaan Mini-CEX. Dengan demikian, persepsi mahasiswa tidak terkait dengan nilai Mini-CEX yang mereka peroleh. Adanya perbedaan yang bermakna $(p<0,05)$ pada perbandingan persepsi mahasiswa antara kedua Bagian dapat disebabkan karena 
perbedaan jumlah pelaksanaan Mini-CEX. Pada Bagian IPD, Mini-CEX dilakukan sebanyak 4 kali, sedangkan pada Ilmu Penyakit Saraf hanya dilakukan sebanyak 2 kali.

\section{KESIMPULAN}

Berdasarkan hasil penelitian, dapat ditarik kesimpulan bahwa menurut pendapat mahasiswa Mini-CEX dapat menjadi media penilaian, media pembelajaran, serta dapat mengembangkan sikap profesionalisme mahasiswa selama kepaniteraan klinik. Saran untuk penelitian selanjutnya adalah diharapkan dapat dilakukan penelitian sejenis dengan subyek penelitian yang lebih besar dan dapat berasal dari universitas yang berbeda untuk mengetahui kemungkinan dampak perbedaan tempat dan budaya belajar mengajar. Karena penelitian ini berdasarkan persepsi mahasiswa, penelitian tentang dampak Mini-CEX terhadap keterampilan klinik mahasiswa dan mekanisme penilaian Mini-CEX mempengaruhi proses pembelajar-an mahasiswa masih diperlukan.

\section{DAFTAR PUSTAKA}

1. Shumway JM, Harden RM. The assessment of learning outcomes for the competent and reflective physician. Medical Teacher. 2003;25(6):569-84.

2. Norcini JJ, Blank LL, Arnold GK, Kimball HR. The mini-CEX: a preliminary investigation. Ann Intern Med. 1995;123(10):795-9.

3. Kogan JR, Bellini LM, \& Shea JA. Feasibility, reliability and validity of the mini clinical evaluation exercise (Mini-CEX) in a medicine core clerkship. Academic Medicine. 2003;78:33-5.

4. Hauer KE. Enhancing feedback to students using the mini-CEX (Clinical Evaluation Exercise). Academic Medicine. 2000;75:524.

5. Holmboe ES, Yepes M, Williams F, and Huot S. Feedback and the Mini Clinical Evaluation Exercise. J Gen Intern Med. 2004;19:558-61.

6. Kogan JR, Hauer KE. Brief report: use of the miniclinical evaluation exercise in internal medicine core clerkships. J Gen Intern Med. 2006;21:501-2.

7. De lima AA, Henquin R, Thierer J, Paulin J, Lamari S, Belcastro F, \& Van der Vleuten, CPM. A qualitative study of the impact on learning of the mini clinical evaluation exercise in postgraduate training. Medical Teacher. 2005:27(1):46-52.

8. Norcini J \& Burch V. Workplace-based assessment as an educational tool: AMEE Guide No. 31. Medical Teacher. 2007; 129:855-71.

9. Alhusni S. Aplikasi statistik praktis dengan SPSS 10. Yogyakarta: Graha Ilmu; 2003.

10. Sugiyono. Statistika untuk penelitian. Bandung: Alfabeta; 2007.

11. Durning SJ, Cation LJ, Market RJ, Pangaro LN. Assessing the reliability and validity of the mini clinical evaluation exercise for internal medicine residency training. Academic Medicine. 2002; 77:900-4.

12. Wilkinson J, Crossley J, Wragg A, Mills P, Cowan G and Wade W. Implementing workplace-based assessment across the medical specialties in the United Kingdom. Medical Education. 2008;42:364-73.

13. Norcini JJ, Blank LL, Duffy D, \& Fortna GS. The mini-CEX: a method for assessing clinical skills. Ann Intern Med. 2003;138:476-81.

14. Van hell EA, Kuks JBM, Raat ANJ, Van Lohuizen, Cohen J. Instructiveness of feedback during clerkships: influence of supervisor, observation and student initiative. Medical Teacher. 2008;31(1):45-50.

15. Nicholson S, Cook V, Naish J, \& Boursicot K. Feedback: its importance in developing medical student's clinical practice. The Clinical Teacher. 2008;5(1):63-166.

16. Malhotra S, Hatala R \& Courneya CA. Internal medicine residents' perceptions of the mini-clinical evaluation exercise. Medical Teacher. 2008;30:4149.

17. Hill F, Kendall K. Adopting and adapting the miniCEX as an undergraduate assessment and learning tool. The Clinical Teacher. 2007;4:244-8.

18. Wragg A, Wade W, Fuller G, Cowan G \& Mills P. Assessing the performance of specialist registrars. Clin Med. 2003;2:131-4.

19. Norcini JJ. The mini clinical evaluation exercise (miniCEX). The Clinical Teacher. 2005;2(1):25-30. 